\title{
ENDOGENOUS PEROXIDASE IN THE EPITHELIUM OVER PEYER'S PATCHES OF RAT SMALL INTESTINE
}

\author{
Hideaki HaSEgaWA, Hiroshi NAGURA** and Keirahi WATANABE*
}

\author{
Cell Biology Research Laboratory and Department of Patholog $y^{*}$, Tokai \\ University School of Medicine, Isehara, Kanagawa 259-11, and \\ Laboratory of Germfree Life**, Research Institute for Disease \\ Mechanism and Control, Nagoya University School of \\ Medicine, Nagoya 466
}

Received for publication March 5, 1985 and in revised form May 24, 1985

\begin{abstract}
Endogenous peroxidases were histochemically demonstrated in epithelial cells over Peyer's patches in the jejunum of the rats. By one week after birth, the peroxidase-positive cells were found in the epithelial cells over the lymphoid aggregate in the jejunum. Those peroxidase-containing epithelial cells increased in number thereafter, while the peroxidase in those in the ileum remained negative. Electron microscopically the peroxidase was localized in the perinuclear spaces, cisternae of the endoplasmic reticulum and apically located cytoplasmic vesicles of the cell. The number of the peroxidase-positive cells in adult germ-free rats was much fewer than that in the conventional, although the distribution patterns of the peroxidase activity in the intestine were similar to each other. In point of the histochemical properties of the enzyme, this epithelial peroxidase appears to be analogous to the peroxidases of some other epithelial cells such as large intestine, salivary and lacrimal glands, and to differ from the myelo-peroxidase in the myeloid-derived cells.
\end{abstract}

During the course of the investigation of the immunohistochemical localizations of immunoglobulin A and secretory component in the epithelial cells of rat gastrointestinal tracts by the "peroxidase"-labeled antibody technique (12), we have noticed a particular type of the epithelium which lies over the Peyer's patches in the jejunum and contains endogenous peroxidase. Although the presence of the endogenous peroxidase in epithelial cells of large intestine has been reported previously (19), this enzyme has never been recognized in the epithelial cells of any other parts of gastrointestinal tracts. Thus, in order to define further the nature of the peroxidase-positive cells, the jejunum of rats was investigated histochemically at both light and electron microscopic levels.

\section{MATERIALS AND METHODS}

Tissues: Conventional Wistar rats, aged 1, 3, 7, 10, 14, 21 and 28 days old, and conventional and germ-free Wistar rats weighing $250 \mathrm{~g}-300 \mathrm{~g}$ were used. The germ-free rats were maintained in a plastic isolator on a sterile commercial diet and water ad libitum (12), and the conventional rats were fed on the same food. Each 
experimental group consisted of three rats. Adult rats were anesthesized under ether, the small intestine was exposed and fixation was initiated by injecting chilled $1 \%$ glutaraldehyde in cacodylate buffer $(0.1 \mathrm{M}, \mathrm{pH} 7.4)$ containing $0.05 \%$ calcium chloride into the intestinal lumen. The nearest segments of intestine containing Peyer's patches from the ligament of Treitz and the ileocecal junction were immediately removed and immersed in the fixative for an additional $30 \mathrm{~min}$ at $4^{\circ} \mathrm{C}$. All parts of the small intestine from suckling rats were fixed. In order to differentiate the activity of the uptaken lactoperoxidase in mother's milk by the epithelial cells from that of the endogenous peroxidase in question, six new born rats, 7-daysold, were separated from their mother and maintained for three days by Hank's solution (10). After three days' feeding on the Hank's solution, three rats out of those six were sacrificed and the entire small intestines were excised and fixed in the fixative mentioned above. The other three were returned to their mother for an additional three days' natural nursing. Then they were sacrificed and their small intestines were treated as described above.

The tissues were washed in $10 \%$ sucrose in cacodylate buffer $(0.1 \mathrm{M}, \mathrm{pH} 7.4)$ for $15 \mathrm{hr}$. They were further washed in increasing concentrations of sucrose and finally placed in $20 \%$ sucrose in cacodylate buffer containing $5 \%$ glycerol. The tissues were embedded in OCT compound (Miles Laboratories, Inc. Naperville, Il. U.S.A.), frozen in a dry ice-ethanol mixture, and sectioned $(6 \mu \mathrm{m})$ in a cryostat. The sections, air dried on the glass slide coated with albumin, were processed for the cytochemical staining.

Histochemical methods: Peroxidase was localized by the method after Fahimi et al. (6). Briefly, after washing the sections 3 times in cacodylate buffer $(0.1 \mathrm{M}$, $\mathrm{pH}$ 7.4), they were first placed in a freshly prepared medium containing only

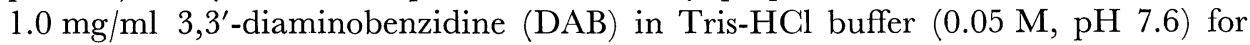
$30 \mathrm{~min}$ at $25^{\circ} \mathrm{C}$. This was followed by the incubation of the sections in a medium containing $0.005 \%-0.01 \% \mathrm{H}_{2} \mathrm{O}_{2}$ and $1.0 \mathrm{mg} / \mathrm{ml} \mathrm{DAB}$ for an additional $30 \mathrm{~min}$ at $25^{\circ} \mathrm{C}$. To establish the specificity of the histochemical reaction for the peroxidase, some sections were placed in the DAB solution which contained $0.01 \mathrm{M}-0.1 \mathrm{M}$ 3-amino-1,2,4-triazole or $0.001 \mathrm{M}-0.01 \mathrm{M}$ sodium azide. For light microscopy, the sections were counterstained with methyl green, dehydrated in ethanol and mounted.

For electron microscopy, the sections were osmicated in $2 \% \mathrm{OsO}_{4}$ in cacodylate buffer $\left(0.1 \mathrm{M}, \mathrm{pH} \mathrm{7.4)}\right.$ ) for one $\mathrm{hr}$ at $25^{\circ} \mathrm{C}$, dehydrated in a graded series of ethanol and embedded in Epon. Ultrathin sections, either unstained or lightly stained with lead citrate, were examined under a JEM-100C electron microscope.

\section{RESULTS}

The results of the present study on the peroxidase localization in the small intestine are summarized in Table 1.

Distribution of peroxidase in neonatal rat tissues Jejunum

One and three days old: No peroxidase activity was found in jejunal epithelial cells. 
TABLE 1. Frequency of the peroxidase-positive cells in the epithelium over the jejunal Peyer's patch

\begin{tabular}{cc}
\hline & Peroxidase-positive cells \\
\hline Neonatal rat & \\
Conventional & - \\
1 day old & - \\
3 days old & + \\
7 days old & + \\
10 days old & + \\
14 days old & + \\
21 days old & + \\
28 days old & \\
Adult rat & + \\
Conventional & + \\
Germ-free & + \\
\hline
\end{tabular}

- : No positive cells

$+:$ Less than one tenth of the epithelial cells over the Peyer's patch

+ : Between $(+)$ and $(H)$

$\mathrm{Ht}$ : More than a half of the epithelial cells over the Peyer's patch

Seven and 10 days old: None of the villus epithelial cells were stained for peroxidase, but the positive staining was noticed as a diffuse pattern in some (but not all) cells within the epithelial layer lying over the lymphoid aggregates (Fig. 1). Electron microscopic enzyme histochemistry revealed the reaction products in the perinuclear spaces, cisternae of the endoplasmic reticulum and cytoplasmic vesicles, and also frequently on the surface of microvilli. In some cytoplasmic vesicles, the interior was filled with the electron-opaque product, and in the others the product was found associated with membranes. In the Golgi apparatus, the lamella were devoid of the reaction products except for a few vesicles associated with the lamella (Fig. 4).

Fourteen days old: The lymphoid follicles which resembled Peyer's patches were formed and the number of peroxidase-positive cells in the epithelial layer lying over the lymphoid follicles increased. No peroxidase activity was found in the villus epithelium.

Twenty one and twenty eight days old: The volume of the lymphoid follicle as well as the number of the peroxidase-positive cells in the epithelial layer lying over the lymphoid follicles were much increased. No peroxidase positive cells were identified in the villus epithelium.

Ileum

During suckling periods, all the villus epithelial cells and some over the lymphoid aggregates or follicles had large vacuoles containing the reaction products of peroxidase in their supranuclear cytoplasm (Figs. 2, 5). Although these epithelial cells still contained the large vacuoles after the feeding by Hank's solution, they were negative for the peroxidase staining (Fig. 3). When the rats were returned to their mother for natural nursing, the cytoplasmic vacuoles regained the peroxidase-positive substance. On the 21st day of life, at the time of weaning, the peroxidase-positive 


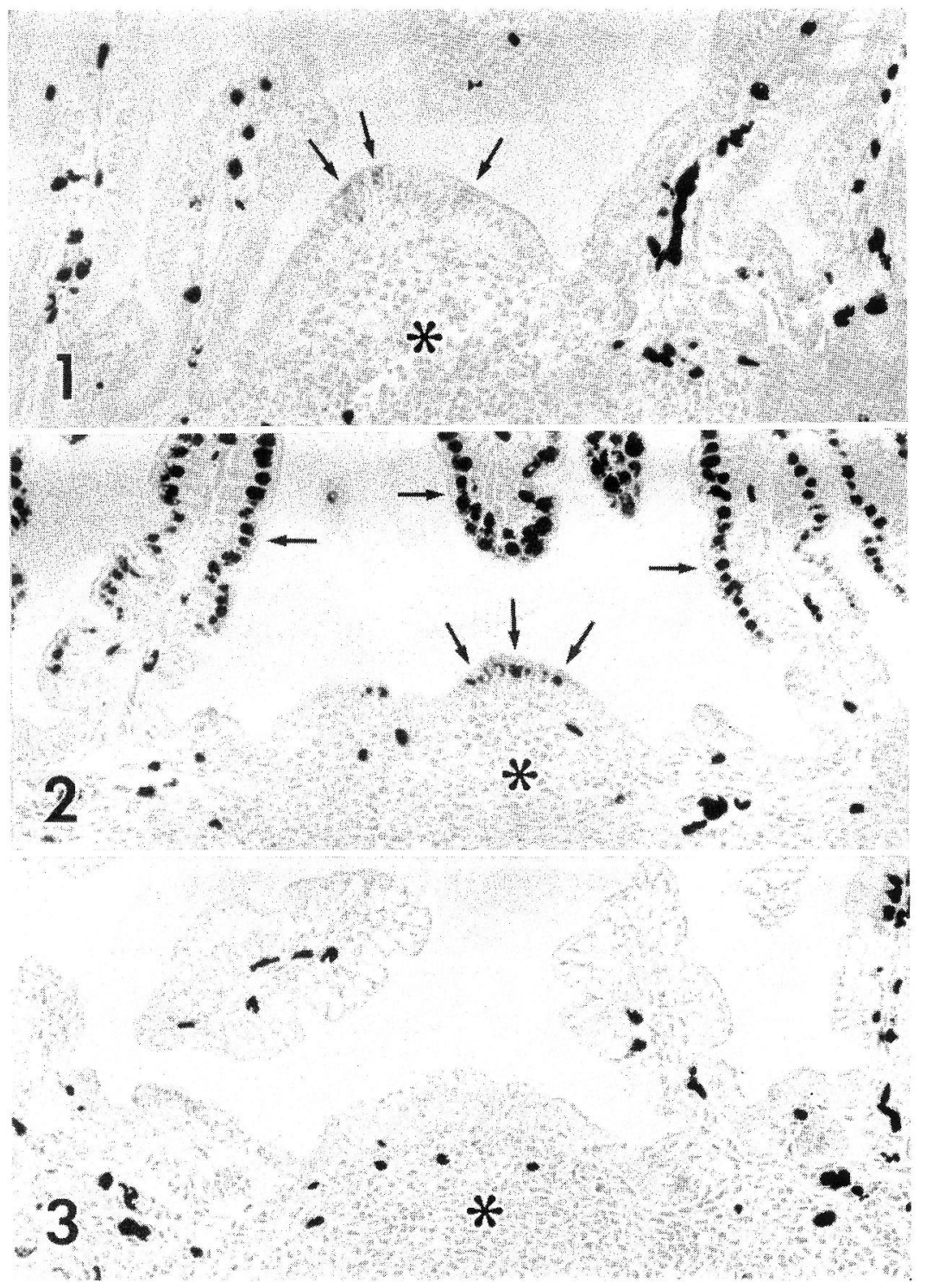

Fig. 1. The peroxidase localization in the jejunal mucosa of a 7-day-old rat. A few cells (arrows) in the epithelial layer lying over the lymphoid aggregate $(*)$ are stained for the peroxidase. Villus epithelial cells are uniformly negative. $\times 330$

FIG. 2. The peroxidase localization in the ileal mucosa of a 7-day-old rat. Cytoplasmic vacuoles (arrows) in the villus epithelial cells contain a strong peroxidase activity. Similar peroxidase positive vacuoles (arrows) are also seen in the epithelial layer lying over the lymphoid aggregate (*). $\times 330$

FIG. 3. The peroxidase localization in the ileal mucosa of a 10-day-old rat maintained for 3 days by Hank's solution. Although cytoplasmic vacuoles remain in the epithelial cells, the peroxidase activity is absent. *: lymphoid aggregate. $\times 330$ 

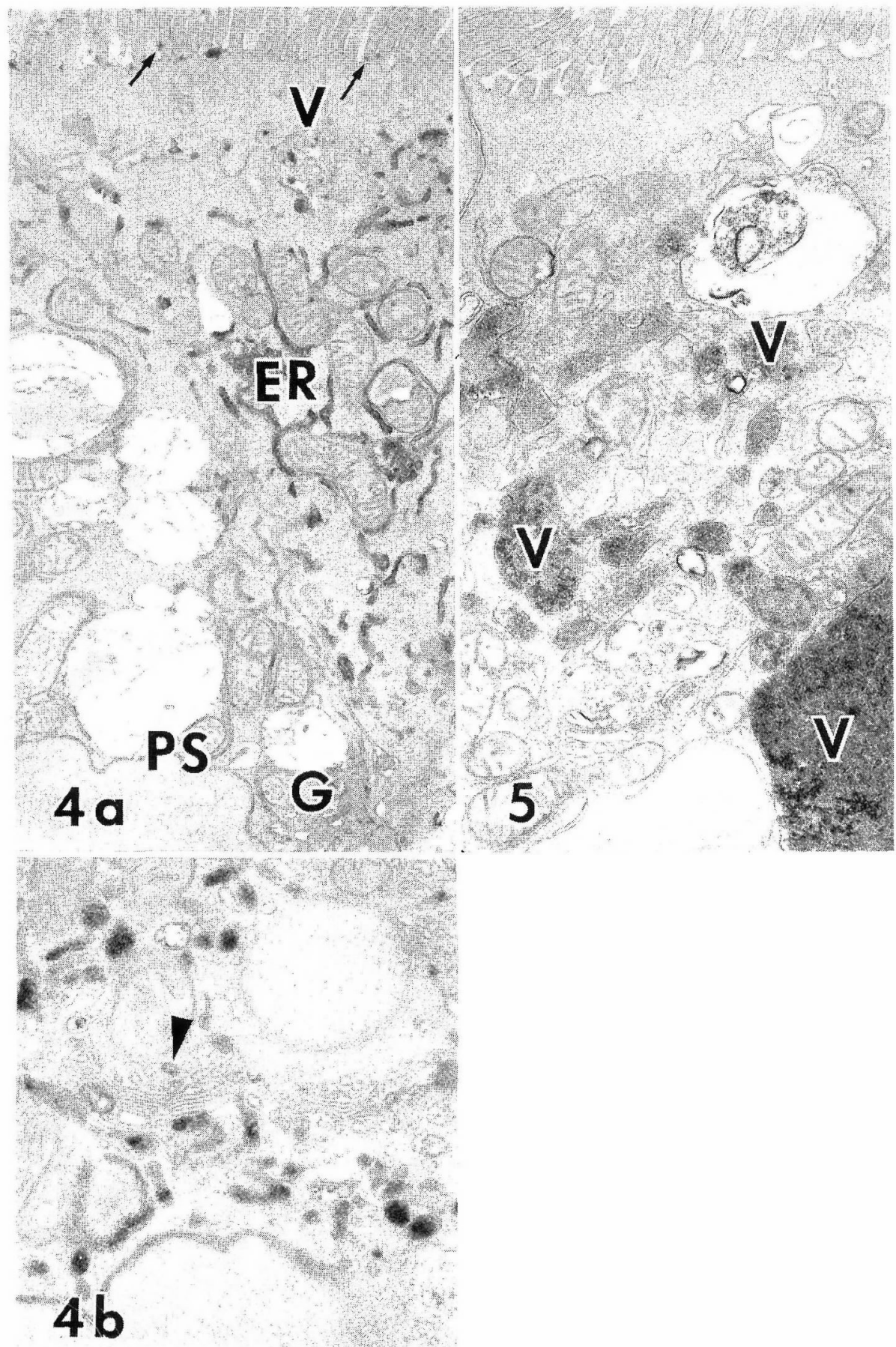
vacuoles in the ileum including the epithelium over the Peyer's patches could no longer be identified.

Distribution of peroxidase in adult conventional rat tissues

Jejunum

The epithelial layer lying over the Peyer's patches always contained numerous peroxidase-positive cells (Fig. 6a). No peroxidase activity could be demonstrated in the villus epithelium (Fig. 6b). Electron microscopic enzyme histochemistry revealed that the intracellular distribution of the peroxidase reaction products was almost identical to that of 7 days old rats, except for the surface of microvilli where no reaction product could be detected. At the apicies of the cells, some peroxidasecontaining rough endoplasmic reticula, which were filled with the electron-opaque precipitate, were extended and oriented perpendicularly to the luminal surfaces of the epithelial cells and their tips were often lying at the closest proximity to the surface membranes. The peroxidase-containing vesicles were also located very close to the base of microvilli. The precipitate was primarily found associated with the membrane, and occasional flecks were present in the interior (Fig. 9).

Ileum

Peroxidase activity was not demonstrated in either the epithelium over the Peyer's patches or the villus epithelium of the ileum (Figs. 7, 10).

Distribution of peroxidase in adult germ-free rat tissues

The number of peroxidase-positive epithelial cells lying over the Peyer's patches in the jejunum were much fewer than those of the conventional adult rats (Fig. 8a). The villus epithelial cells of both jejunum and ileum were negative for the peroxidase staining as in the conventional adult rats (Fig. 8b).

\section{Effects of inhibitors}

When the tissue sections were incubated in the reaction medium containing $0.1 \mathrm{M}$ 3-amino-1,2,4-triazole or $0.005 \mathrm{M}$ sodium azide, no enzyme activity was found in the epithelium over the Peyer's patches, whereas the peroxidase of myeloidderived cells in the lamina propria were still intensely stained (Figs. 11, 12).

\section{DISGUSSION}

The present enzyme histochemical study has revealed an endogenous peroxidase in a particular type of the epithelial cells previously unspecified. To our knowledge, there is no report which demonstrates the presence of peroxidases in the epithelium of the small intestine, though the enzyme has been demonstrated histochemically in colonic mucosa by Venkatachalam et al. (19). The peroxidase-positive cells began

Figs. 4a, b. The ultrastructural localization of the peroxidase in the epithelial cell rich in microvilli over the jejunal Peyer's patch of a 7-day-old rat. The reaction products are present in the perinuclear spaces (PS), endoplasmic reticulum (ER) and cytoplasmic vesicles (V), and on the surface of microvilli (arrows). In Golgi apparatus (G), no reaction products are identified in almost all lamella. An arrowhead illustrates peroxidase-positive vesicles by the outermost lamella in the trans side. a. $\times 16,000$, b. $\times 29,000$

FIG. 5. The ultrastructural localization of the peroxidase in the epithelial cell rich in microvilli over the ileal Peyer's patch of a 7-day-old rat. The reaction products are present in the large vacuoles (V). No reaction products are found in the protein-synthetic organella. $\quad \times 16,000$ 


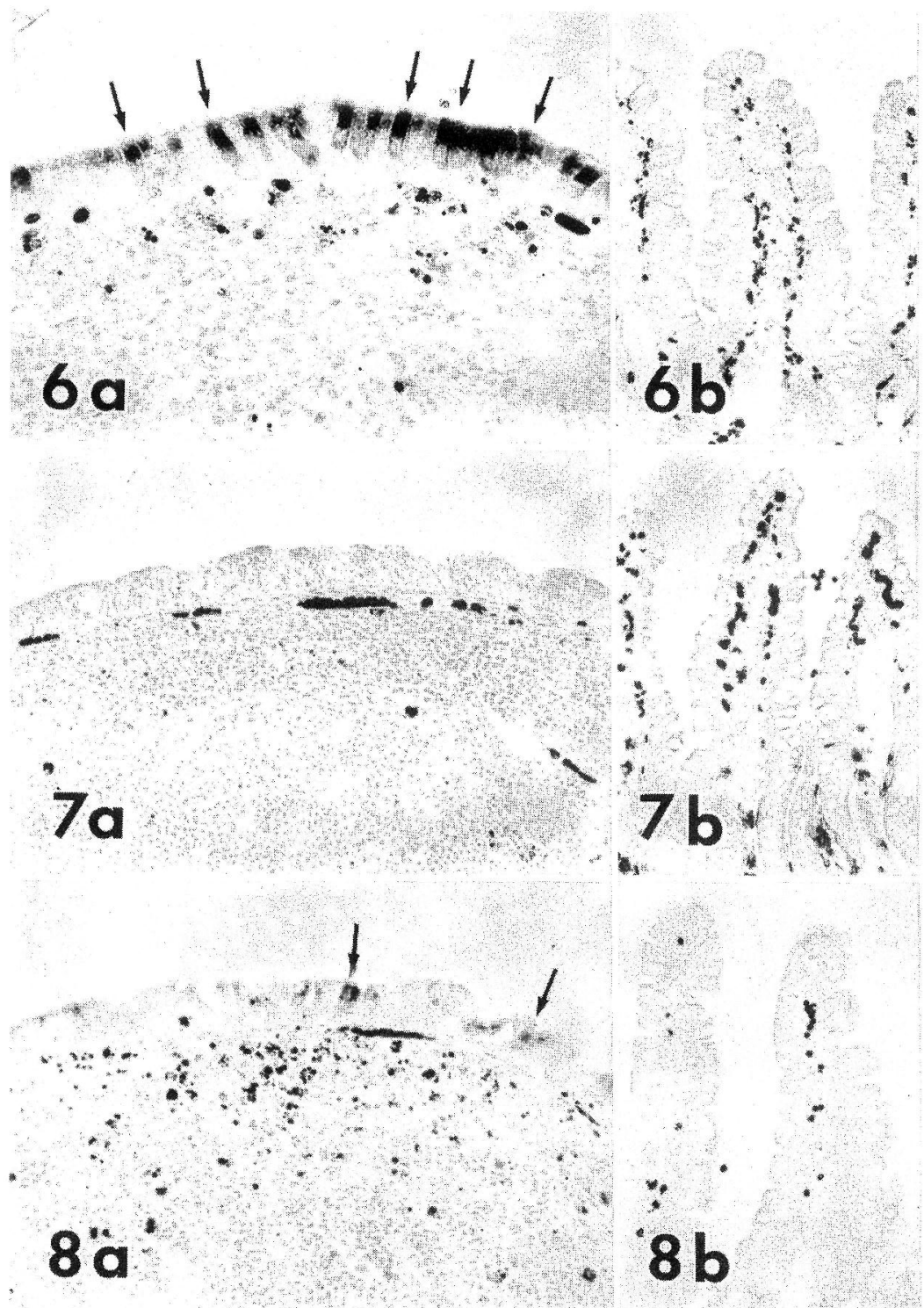

Figs. 6a, b. Jejunal Peyer's patch (a) and villi (b) of an adult rat. a. Numerous peroxidasepositive cells (arrows) are present in the epithelial layer lying over the Peyer's patch. $\times 260$ b. The strong peroxidase staining is seen in myeloid-derived cells (mostly neutrophils) in the lamina propria but not in the villus epithelial cells. $\times 150$

FIGs. 7a, b. Ileal Peyer's patch (a) and villi (b) of an adult rat. a. No peroxidase activity is visible in the epithelial layer lying over the Peyer's patch. $\times 260$ b. The similar histochemical feature as in Fig. $6(\mathrm{~b})$ is observed. $\times 150$

Figs. 8a, b. Jejunal Peyer's patch (a) and villi (b) of an adult germ-free rat. a. The peroxidasepositive epithelial cells (arrows) are much fewer than those seen in the conventional rat as shown in Fig. 6(a). $\times 260$ b. Myeloid-derived cells in the lamina propria, which are strongly stained for the peroxidase, are much fewer than those recognized in the conventional rat. Villus epithelial cells are negative for the enzyme activity. $\times 150$ 


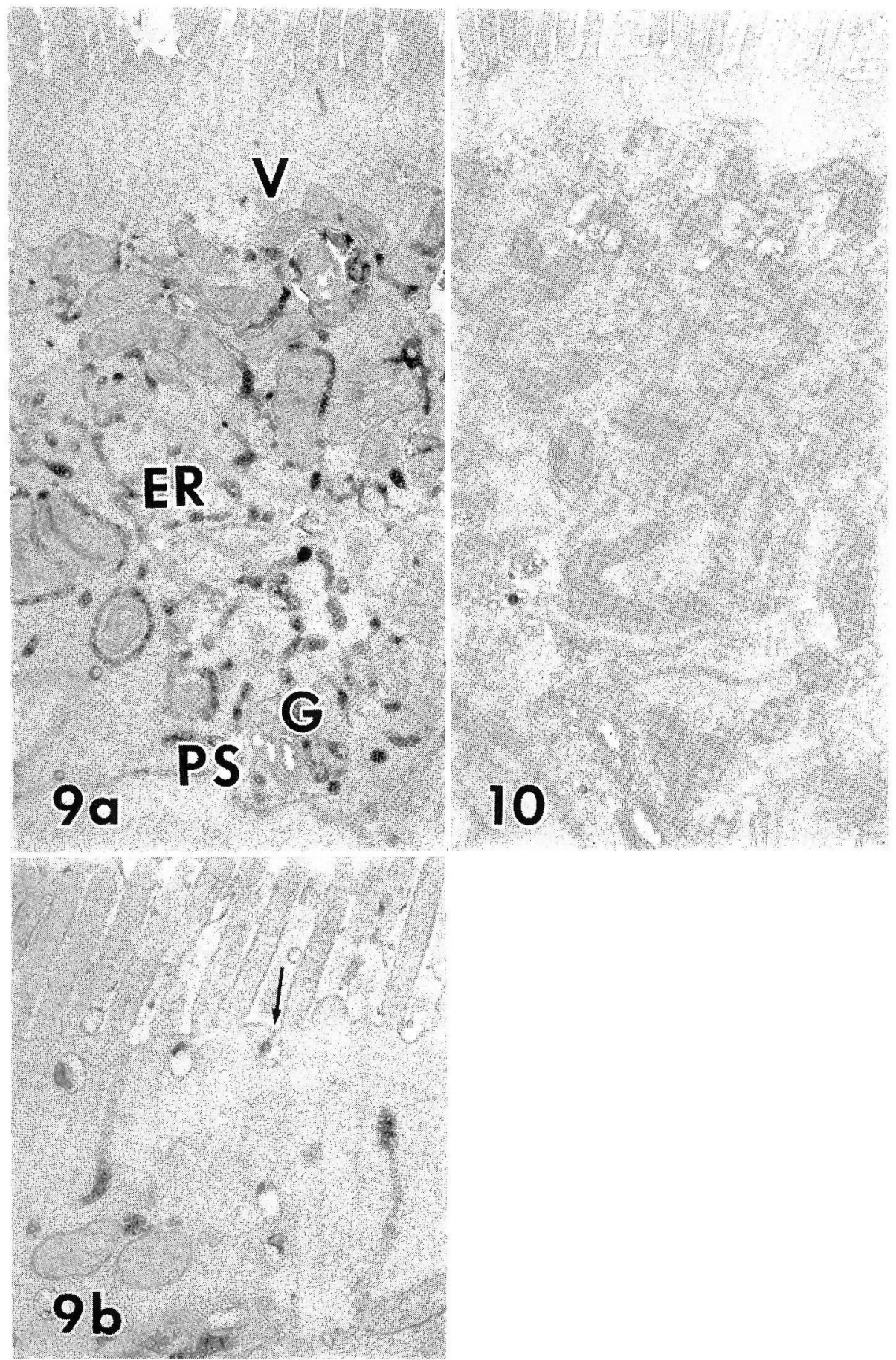




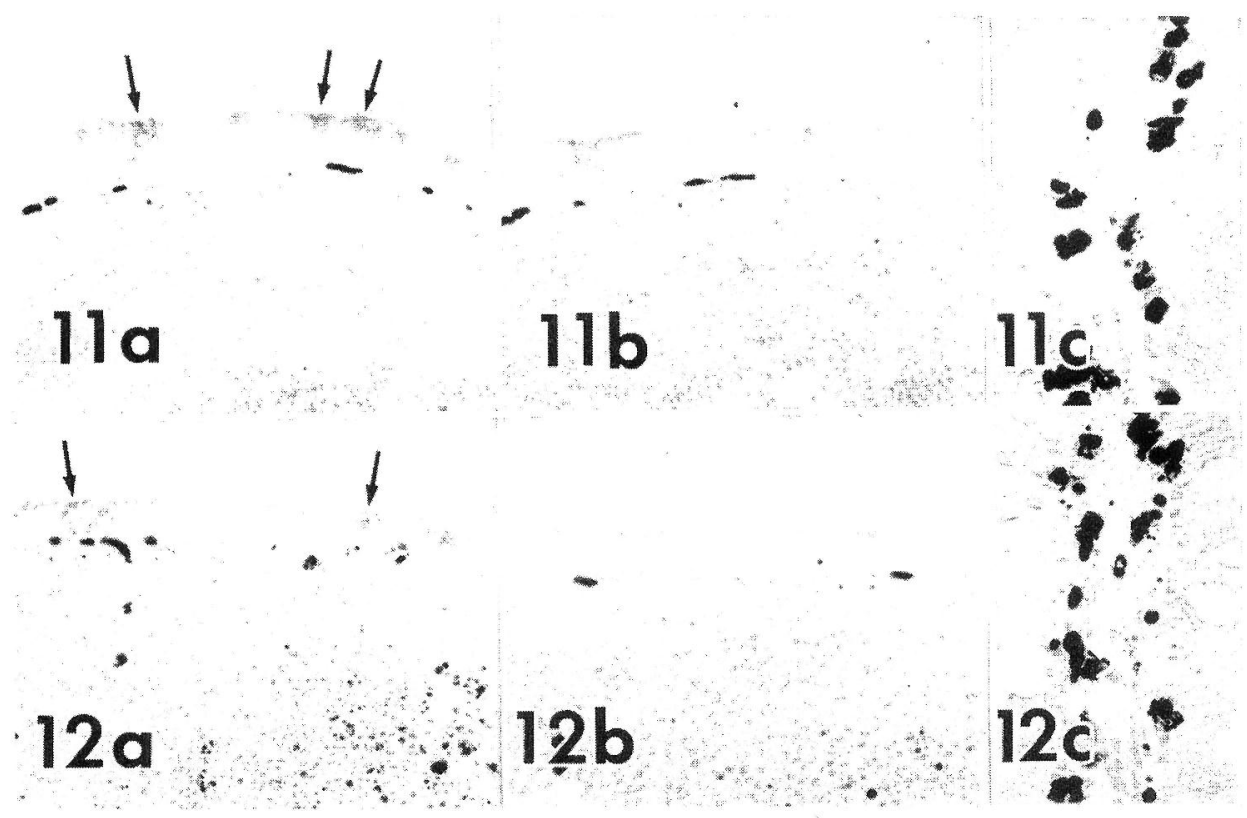

FIGS. 11a-c. Inhibition test for the peroxidase activity in the jejunal Peyer's patch (a, b) and villi (c) with $0.05 \mathrm{M}(\mathrm{a})$ and $0.1 \mathrm{M}(\mathrm{b}, \mathrm{c})$ of 3-amino-1,2,4-triazole. a. The relatively strong enzyme activity remains in some epithelial cells (arrows) under this concentration. $\times 260 \mathrm{~b}$. The enzyme activity is almost completely abolished. $\times 260$ c. The strong enzyme activity remains in the myeloid-derived cells in the lamina propria. $\times 360$

FIgs. $12 \mathrm{a}-\mathrm{c}$. Inhibition test for the peroxidase activity in the jejunal Peyer's patch (a, b) and villi (c) with $0.001 \mathrm{M}(\mathrm{a})$ and $0.005 \mathrm{M}(\mathrm{b}, \mathrm{c})$ of sodium azide. a. A few epithelial cells (arrows) contain the weak enzyme activity. $\times 260$ b. The enzyme activity is completely inhibited with this concentration. $\times 260$ c. The strong enzyme activity remains in the myeloid-derived cells in the lamina propria. $\times 360$

to appear one week after birth in the epithelium over the lymphoid aggregates. The number of those cells in the epithelium increased with age and the lymphoid aggregates developed to form Peyer's patches.

Such peroxidase-positive cells as mentioned above were located in the epithelial layer lying over the Peyer's patches in the jejunum but not in the ileum of the rats. During suckling periods, however, the ileum also exhibited many peroxidase-positive epithelial cells of villi and those lying over the lymphoid aggregates or follicles (precursory apparati of Peyer's patches). The intracellular localization pattern of

Figs. 9a, b. The ultrastructural localization of the peroxidase in the epithelial cell rich in microvilli over the jejunal Peyer's patch of an adult rat. The localization of the enzyme is similar to that seen in new born rat as shown in Fig. 4. At the apical region, vesicles containing the peroxidase are present in the cytoplasm immediately beneath the microvilli. An arrow indicates a vesicle opening to the exterior. V: cytoplasmic vesicle, ER: endoplasmic reticulum, PS: perinuclear space, G: Golgi apparatus. a. $\times 18,000 \quad$ b. $\times 29,000$

Frg. 10. The ultrastructural localization of the peroxidase in the epithelial cell rich in microvilli over the ileal Peyer's patch of an adult rat. No reaction products are found. $\times 18,000$ 
the peroxidase in those cells was quite different from that in peroxidase-positive cells demonstrated in the jejunum; that is, the reaction products of the peroxidase were localized in the large supranuclear endocytotic or storage vacuoles in the ileum (Fig. 5), whereas protein synthetic organella, such as perinuclear spaces and the cisternae of rough endoplasmic reticulum, were the predominant localization sites in the jejunum (Figs. 4, 9). When those neonatal rats were maintained by Hank's solution instead of mother's breast milk for three days, the similar cytoplasmic (endocytotic or storage) vacuoles were still present but the peroxidase was not detected in them. After weaning, those cytoplasmic vacuoles disappeared from the epithelial cells of the ileum, as shown previously (10). This indicates that the peroxidase in the epithelial cells of the ileum in the suckling rats is most likely the lactoperoxidase (2) derived from the mother's milk. In fact, it has been proved that ileal epithelial cells in the suckling rats can nonspecifically uptake various protein molecules in breast milk, such as $\operatorname{IgG}$ and $\operatorname{IgA}$, whereas jejunal epithelial cells can not $(10)$.

By ultrastructural observations of those peroxidase-positive epithelial cells lying over the Peyer's patches, the enzyme was exclusively localized in a specific cell type which was rich in microvilli on the luminal surface and was devoid of mucous vacuoles. In this context, the cell is clearly different from mucous secreting goblet cells and so-called M-cells which are characterized by luminal surface microfolds and uptaking antigenic substances from gut lumina (14).

The peroxidase contained in the epithelial cells was very sensitive to the inhibitory effect of 3-amino-1,2,4-triazole and sodium azide, though the peroxidase activity in the myeloid-derived cells in the lamina propria was relatively resistant to these inhibitors (Figs. 11, 12). Accordingly, this enzyme in the epithelial layer lying over the Peyer's patches is clearly heterogenous with the myeloperoxidase $(1,3)$. Considering these histochemical properties of the peroxidase-positive epithelial cells, they seem to share a common denominator with some other peroxidase-positive epithelial cells of the large intestine (19), larynx (9), trachea (4), lacrimal $(5,8)$ and salivary glands $(7,20)$. Furthermore, the intracellular localization pattern of the peroxidase in the epithelial cells of the jejunum, i.e. in perinuclear spaces, cisternae of rough endoplasmic reticulum and apical vesicles which are common localization sites for most of secretory proteins, was quite similar to that of those epithelial cells of the organs mentioned above. It was postulated in those reports that those epithelial cells were synthesizing and secreting their peroxidases externally. Thus, the peroxidase observed in the present study would be a protein of secretory nature. In mature plasma cells, for example, which are definitely secreting various immunoglobulins, immunoglobulin proteins are exclusively localized in perinuclear spaces and cisterna of rough endoplasmic reticulum, but not in Golgi complex (11).

Golgi complex in the epithelial cells over the jejunal Peyer's patches was unreactive (Figs. 4, 9), and that in the epithelial cells of the other tissues, such as lacrimal glands and salivary glands $(8,20)$, also produces only a little or no visible cytochemical stain. With respect to the influence of $\mathrm{H}_{2} \mathrm{O}_{2}$ on peroxidases, Roels et al. (16) have reported the inhibition of peroxidase activity by higher concentration of $\mathrm{H}_{2} \mathrm{O}_{2}$. In our experimental conditions, $0.005 \% \mathrm{H}_{2} \mathrm{O}_{2}$ for the localization of peroxidase yielded the same staining intensity as $0.01 \%$ after the technique of 
Fahimi et al. (6). Roels et al. (16) also failed to localize peroxidases in the Golgi complex with $0.003 \% \mathrm{H}_{2} \mathrm{O}_{2}$.

The localization pattern of peroxidase-positive cells in the germ-free adult rats was identical to that in the conventional. However, it was noticeable that the number of the peroxidase-positive cells in the germ-free adult rats was much fewer than that in the conventional adult rats. These findings would indicate that the number of the peroxidase-positive cells is influenced by enteric organisms. The other epithelial peroxidases, such as peroxidase of the lacrimal glands $(5,8)$, salivary glands $(7,20)$ and mammary glands (2) are postulated to have a bactericidal function $(15,17,18)$. Although the bactericidal activity of this intestinal peroxidase was not tested in the present study, it is conceivable that this enzyme might have a similar function, together with secretory IgA and lactoferrin which are secreted by the epithelial cells of intestines and these glands $(12,13)$.

\section{ACKNOWLEDGEMENT}

The authors thank Professor Paul K. Nakane, Department of Cell Biology, Tokai University School of Medicine, for reading and offering criticisms of the manuscript. We acknowledge the skillful assistances of $\mathrm{Mr}$. Jobu Ito and Ms. Mutsuko Ohshiba.

\section{REFERENCES}

1. Ackerman, G. A. and Clark, M. A.: Ultrastructural localization of peroxidase activity in normal human bone marrow cells. Z. Zellforsch. 117; 463-475, 1971.

2. Anderson, W. A., Trantalis, J. and Kang, Y. H.: Ultrastructural localization of endogenous mammary gland peroxidase during lactogenesis in the rat. Results after tannic acidformaldehyde-glutaraldehyde fixation. J. Histochem. Cytochem. 23; 295-302, 1975.

3. Bainton, D. F. and Farquhar, M. G.: Segregation and packaging of granule enzymes in eosinophilic leukocytes. J. Cell Biol. 45; 54-73, 1970.

4. Christensen, T. G., Blanchard, G. G., Nolley, G. and Hayes, J. A.: Ultrastructural localization of endogenous peroxidase in the lower respiratory tract of the guinea pig. Cell Tissue Res. 214; 407-415, 1981.

5. Essner, E.: Localization of endogenous peroxidase in rat exorbital lacrimal gland. J. Histochem. Cytochem. 19; 216-225, 1971.

6. Fahimi, H. D., Gray, B. A. and Herzog, V. K.: Cytochemical localization of catalase and peroxidase in sinusoidal cells of rat liver. Lab. Invest. 34; 192-201, 1976.

7. Herzog, V. and Miller, F.: Die Lokalisation endogener Peroxydase in der Glandula parotis der Ratte. Z. Zellforsch. 107; 403-420, 1970.

8. Herzog, V. and Miller, F.: The localization of endogenous peroxidase in the lacrimal gland of the rat during postnatal development. J. Cell Biol. 53; 662-680, 1972.

9. Kataoka, K.: Fine structural localization of peroxidase activity in the epithelium and the gland of the rat larynx. Histochemie 26; 319-326, 1971.

10. Nagura, H., Nakane, P. K. and Brown, W. R.: Breast milk IgA binds to jejunal epithelium in suckling rats. J. Immunol. 120; 1333-1339, 1978.

11. Nagura, H., Kohler, P. F. and Brown, W. R.: Immunocytochemical characterization of the lymphocytes in nodular lymphoid hyperplasia of the bowel. Lab. Invest. 40; 66-73, 1979.

12. Nagura, H., Hasegawa, H., Yoshimura, S., Aihara, K., Watanabe, K., Sawamura, S. and Ozawa, A.: Comparative immunohistochemical studies on conventional and germfree rat 
intestinal mucosa: with special reference to microbial flora and secretory $\operatorname{IgA}(\mathrm{sIgA})$. In Recent Advances in Germfree Research, ed. by S. Sasaki, A. Ozawa and K. Hashimoto, Tokai University Press, Tokyo, 1981, pp. 511-517.

13. Nakamura, T., Nagura, H., Komatsu, N. and Watanabe, K.: Immunocytochemical and enzyme cytochemical studies on the intracellular transport mechanism of secretory immunoglobulin A and lactoferrin in human salivary glands. Virchows Archiv A: In press.

14. Owen, R. L. and Jones, A. L.: Epithelial cell specialization within human Peyer's patches: an ultrastructural study of intestinal lymphoid follicles. Gastroenterology 66; 189-203, 1974.

15. Reiter, B. and Oram, J. D.: Bacterial inhibitors in milk and other biological fluids. Nature $216 ; 328-330,1967$.

16. Roels, F., Wisse, E., De Prest, B. and van der Meulen, J.: Cytochemical discrimination between catalases and peroxidases using diaminobenzidine. Histochemistry 41; 281-312, 1975.

17. Slowey, R. R., Eidelman, S. and Klebanoff, S. J.: Antibacterial activity of the purified peroxidase from human parotid saliva. J. Bacteriol. 96; 575-579, 1968.

18. Steele, W. F. and Morrison, M.: Antistreptococcal activity of lactoperoxidase. J. Bacteriol. $97 ; 635-639,1969$.

19. Venkatachalam, M. A., Soltani, M. H. and Fahimi, H. D.: Fine structural localization of peroxidase activity in the epithelium of large intestine of rat. J. Cell Biol. 46; 168-173, 1970.

20. Yamashina, S. and Barka, T.: Peroxidase activity in the developing rat submandibular gland. Lab. Invest. 31; 82-89, 1974. 